\title{
Does IFRS Convergence Decrease Earning Manipulation? An Empirical Study of Indonesia
}

\author{
Anis Chariri ${ }^{1 *}$, Athur Tedo Basundara ${ }^{2}$ \\ ${ }^{1,2}$ Faculty of Economics \& Business, Universitas Diponegoro, Semarang, Indonesia
}

\begin{abstract}
This study aims at investigating the effect of IFRS convergence on earning manipulation of companies listed on the Indonesia Stock Exchanges (IDX). Data were gathered from the annual reports of the companies. Samples are determined using purposive sampling and resulted in 51companies. Earning manipulation is measured by Beneish M-Score and then is analysed using Wilcoxon Sign Rank test. Research findings showed there was no significant difference in earning manipulation before and after IFRS convergence. In other words, the IFRS convergence did not decrease earning manipulation practices among companies used as sample in this study
\end{abstract}

Keywords: Earning manipulation, IFRS convergence, Indonesia Stock Exchange, Beneish M-Score

\section{INTRODUCTION}

Earning manipulation has been considered as interesting issue in accounting literature in the last two decades and has attracted accounting scholars to investigative such an issue. It is believed that earning manipulation may occur because of lack of transparency in providing accounting information, especially the implementation of national accounting standards. This is the reason why most countries, including Indonesia, are motivated to adopt International Financial Reporting Standards (IFRS) as basis for preparing and presenting accounting information. In 2012, Indonesia has been completely converged to IFRS and IAI will continuosly adapt to IFRS changes. By doing so, the IFRS convergence is believed by IAI to produce high quality financial reports and eventually reduce fraudulent financial statements, especially earning manipulation.

\footnotetext{
*Email address: anis_chariri@live.undip.ac.id
}

The increasing number of countries adopting IFRS has attracted accounting scholars to investigate such adoption [2]. However, it is questionable whether the implementation of IFRS can reduce earning manipulation. In fact, a number of studies show contradicting findings. On one hand, companies espousing IFRS tend to publish more information which makes them more transparent and reduce earning management [12]; [2]; [13]; [14]; [15]. On the other hand, several studies provided empirical evidence that IFRS did not prevent management to involve in earning manipulation [17]; [18]; [19]; [20]; [21]; [22]. Unfortunately, it is not easy to find empirical studies on the IFRS convergence and earning manipulation in emerging markets, especially in Indonesia.

The main objective of this study is to investigates the effect of IFRS convergence on earning manipulation of the companies. Hence, this study contributes to studies on earning manipulation before and after the IFRS convergence committed by companies in an emerging capital market. Moreover, this study employs Beneish MScore as proxy of earning manipulation. 


\section{IFRS CONVERGENCE AND EARNING MANIPULATION}

Implementatiton of IFRS-convergent accounting standards can be related to compliance theory as proposed by Cialdini and Goldstein [23]. They believe that business organizations can be seen as utilitarian-calculative one. Indeed, business organizations are calculative in regard to how the implementation or adoption of any rules or regulations provide them with some benefits instead of having liabilities. Therefore, companies will implement and comply with accounting standards in the preparation of financial statement as long as they believe that such standards contain beneficiary elements for them. Compliance theory explains the reason why companies eager to comply with IFRS. As global accounting standards, IFRS are believed to boost comparability of financial reports which is really beneficial for companies.

According to Bova \& Pereira, IFRS adoption boosted transparency of financial information in Kenya as the fact that IFRS decreases managerial discretion and enforces greater disclosure requirements compared to domestic accounting standards[24]. Moreover, Barth, Landsman, and. Lang [13] confirm that firms which adopted international accounting standards were less involved in earning management than those keep employing domestic accounting standards in their financial reports. Therefore, this study proposes hypothesis as follow:

$H_{A}$ : Earning manipulation practice in the period after IFRS convergence is lower than that in the period before IFRS convergence.

\section{RESEARCH METHODS}

Beneish M-Score [25] is used as a measure of earning manipulation. This Score consists of eight indexes calculated from data of two consecutive year annual reports (except for Total Accruals to Total AssetsTATA): Day's Sales Receivables Index (DSRI), Gross Margin (GMI), Asset Quality Index (AQI), Sales Growth Index (SGI), Depreciation Index (DEPI), Sales, General and Administrative expenses Index (SGAI), Leverage Index (LVGI), and Total Accruals to Total Assets (TATA). Based on those indexes the Beneish Model takes a company's results of these eight variables and applies them in the following formula:

$$
\begin{aligned}
\mathrm{M}= & -4.84+0.92 * \mathrm{DSRI}+0.528^{*} \mathrm{GMI}+0.404 * \mathrm{AQI}+ \\
& 0.892 * \mathrm{SGI}+0.115 * \mathrm{DEPI}-0.172 * \mathrm{SGAI}+ \\
& 4.679 * \text { TATA }-0.327 * \text { LVGI }
\end{aligned}
$$

In the Beneish Model, a score of greater than -2.22 (i.e., less of a negative) shows that there is high possibility of earning manipulation.

The population consist of companies listed in the IDX for the period before IFRS (2007) and after IFRS convergence (2013). Samples are companies with the following criteria: 1) publish complete annual reports in the IDX website; 2) adopted Indonesian Rupiahs (IDR) as currency in their annual reports; 3 ) exhibited the use of IFRS as basis of preparing financial reports. Wilcoxon-
Signed Rank Test (non-parametric) is applied to test the hypothesis (with significance level at 0.05 ) by comparing two paired samples (before and after IFRS convergence.

Table.1. Sample Selection

\begin{tabular}{lc}
\hline \multicolumn{1}{c}{ Sample Criteria } & Companies \\
\hline Listed in the IDX 2013 & 445 \\
Did not published its fin. statement in & $(40)$ \\
2013 & \\
Used foreign currency (not in IDR) & $(22)$ \\
Did not provide complete information & $(176)$ \\
\hline Number of qualified companies & 207 \\
Companies with unavailable financial & $(156)$ \\
$\quad$ data in 2006 for Beneish ratio & \\
\hline Number of samples & 51 \\
\hline
\end{tabular}

\section{FINDINGS AND DISCUSSION}

A number of all companies did not have data required in the study. Samples of 51 observed companies in this study can be seen in Table 1. Table 2 described descriptive statistics of Beneish M-Score before and after IFRS convergence.

Table.2. Beneish M-Score

\begin{tabular}{lccccc}
\hline & N & Min & Max & Mean & $\begin{array}{c}\text { Std. } \\
\text { Dev }\end{array}$ \\
\hline BEF IFRS & 51 & -8.64 & 0.43 & -2.84 & 1.20 \\
AFT IFRS & 51 & -7.55 & -0.05 & -2.77 & 1.22 \\
\hline Valid N (listwise) & 51 & & & & \\
\hline
\end{tabular}

Table.3. Wilcoxon Sign Rank Test (Before VS After IFRS)

AFT IFRS - BEF IFRS

Z

$-.769^{\mathrm{a}}$

Asymp. Sig. (2-tailed)

.442

a. Based on negative ranks

It can be seen from Table 2 that in the period before IFRS Beneish M-Score has mean value of -2.84 , with 0.43 maximum value, -8.64 minimum value and 1.20 standard deviation value. The value of standard deviation - lower than its mean value - means that each Beneish M-Score has relatively low variation. In other words, there are only little differences in each scores. The period after IFRS has similar results with mean value of 2.77; maximum value of -0.05 ; minimum value of -7.55 and standard deviation value of 1.22. Since the mean value is higher than its standard deviation value, these figures implied that this period has also relatively low variation. It means there are only small differences between each M-Score. 
Based on normality test, $\mathrm{W}$ value are 0,625 and 0,703 not exceeds of 1 in both period. It means that data are not normally distributed. Since the data are not normal, nonparametric test was employed to analyse data.

From Table 3, it can be seen that the value of the Asymp. Significant (2-tailed) is higher than the significance level used in this study (0.05) concluding that hypothesis is not supported. This means that there is no statistically significant difference in Beneish M-Score between period before IFRS and period after IFRS. This findings is in contrary with the arguments and findings of other studies which believed that implementation of IFRS reduce the practice of earning management or manipulation[10][3][5]. However, finding of this study is similar to that by Ton [28] showing that there was no difference in the earning management practice after the IFRS adoption in Dutch companies.

There are several reasons why IFRS adoption (convergence) was not able to deter earning manipulation. According to Ton [28] country specific factors play an important role in the success of IFRS implementation. Indeed, mandatory adoption of IFRS is more succesful in countries with stronger investor protection [11]. Furthermore there are three factors that affect the adoption of IFRS in deterring earning manipulation (Ton 2011): (1) the quality of the standards that were used before IFRS, (2) the country's legal and political system and (3) the financial reporting incentives of companies in that country. The three factors may need a comprehensive study which is beyond the area of this research. Additionally, the Beneish M-Score seems to be not suitable for Indonesian companies because a lot of companies were eliminated as observed sample due to incomplete information. This may deteriorate of the research findings.

\section{CONCLUSION AND LIMITATIONS}

This study is intended to analyze the effect of IFRS convergence on earning manipulation practice. The findings showed that IFRS convergence does not have any significant impact on earning manipulation practice in Indonesia. By using Beneish M-Score, this research compared Beneish M-Scores (as proxy of earning manipulation) between the period before and after IFRS convergence. This study found that there was no significant difference in Beneish M-Scores before and after IFRS convergence. This implies that adoption of IFRS did not decrease earning manipulation among samples used in this research. This study contibuted to studies on earning manipulation in regard to IFRS convergence especially from emerging capital markets. Despite the interesing findings, this study suffered from a limitation. Beneish M-Score apparently does not fit with the characteristics of Indonesian companies. More than 150 companies were excluded from observed samples due to incomplete data.

\section{REFERENCES}

[1] D. Desyana, "Kerugian Bank Century Rp 9,15 Triliun.” 2009.

[2] W. R. Landsman, E. L. Maydew, and J. R. Thornock, "The information content of annual earnings announcements and mandatory adoption of IFRS," J. Account. Econ., vol. 53, no. 12, pp. 34-54, Feb. 2012.

[3] F. Aubert and G. Grudnitski, "Analysts estimates: What they could be telling us about the impact of IFRS on earnings manipulation in Europe," Rev. Account. Financ., vol. 11, no. 1, pp. 53-72, Feb. 2012.

[4] R. Ball, "International Financial Reporting Standards (IFRS): Pros and Cons for Investors," Account. Bus. Res. Int. Account. Policy Forum, pp. 5-27, 2006.

[5] A. Ballas, D. Skoutela, and C. Tzovas, "The relevance of IFRS to an emerging market: evidence from Greece," Manag. Financ., vol. 36, no. 11, pp. 931-948, 2010.

[6] F. v Beest, "Rules-Based and Principles-Based Accounting Standards and Earnings Management," NiCE Work. Pap., pp. 09-114, 2009.

[7] S. Calao and J. I. Jarne, "Have IFRS Affected Earnings Management in the European Union? Accounting in Europe," Account. Eur., vol. 7, no. 2, pp. 159-189, 2010.

[8] M.-C. Wu, Y.-T. Huang, and Y.-J. Chen, "Earnings Manipulation, Corporate Governance and Executive Stock Option Grants: Evidence from Taiwan," Asia-Pacific J. Financ. Stud., vol. 41, no. 3, pp. 241-257, 2012.

[9] S. Goel, "Demystifying Earnings Management Through Accruals Management: An Indian Corporate Study," Vikalpa J. Decis. Makers, vol. 37, no. 1, pp. 49-56, 2012.

[10] W. A. Wan Ismail, K. A. Kamarudin, T. Van Zijl, and K. Dunstan, "Earnings quality and the adoption of IFRS-based accounting standards: Evidence from an emerging market," Asian Rev. Account., vol. 21, pp. 53-73, 2013.

[11] M. N. Houqe, T. van Zijl, K. Dunstan, and A. K. M. W. Karim, "The Effect of IFRS Adoption and Investor Protection on Earnings Quality Around the World," Int. J. Account., vol. 47, no. 3, pp. 333-355, Sep. 2012.

[12] R. Fu, A. Kraft, and H. Zhang, "Financial reporting frequency, information asymmetry, and the cost of equity," J. Account. Econ., vol. 54, no. 2-3, pp. 132-149, 2012.

[13] M. E. Barth, W. R. Landsman, and M. H. Lang, "International Accounting Standards and Accounting Quality," J. Account. Res., vol. 46, no. 3, pp. 467-498, 2008.

[14] D. Zéghal, S. Chtourou, and Y. M. Sellami, "An analysis of the effect of mandatory adoption of IAS/IFRS on earnings management," J. Int. Accounting, Audit. Tax., vol. 20, no. 2, pp 61-72, Jan. 2011.

[15] G. Iatridis, "Hedging and earnings management in the light of IFRS implementation: Evidence from the UK stock market," $B r$. Account. Rev., vol. 44, no. 1, pp. 21-35, Mar. 2012.

[16] P. E. Dimitropoulos, D. Asteriou, D. Kousenidis, and S. Leventis, "The impact of IFRS on accounting quality: Evidence from Greece," Adv. Account., vol. 29, no. 1, pp. 108-123, Jun. 2013.

[17] M. L. DeFond, "Earnings quality research: Advances, challenges and future research," J. Account. Econ., vol. 50, no. 2-3, pp. 402-409, Dec. 2010.

[18] Y. Wang and M. Campbell, "Corporate governance, earnings management, and IFRS: Empirical evidence from Chinese domestically listed companies," Adv. Account., vol. 28, no. 1, pp. 189-192, Jun. 2012.

[19] D. Cormier and I. Martinez, "The association between management earnings forecasts, earnings management, and stock 
market valuation: Evidence from French IPOs," Int. J. Account., vol. 41, no. 3, pp. 209-236, Jan. 2006.

[20] Y. Zhang, K. Uchida, and H. Bu, "How do accounting standards and insiders' incentives affect earnings management? Evidence from China," Emerg. Mark. Rev., vol. 16, pp. 78-99, Sep. 2013.

[21] D. Ghosh and L. Olsen, "Environmental uncertainty and managers' use of discretionary accruals," Accounting, Organ Soc., vol. 34, no. 2, pp. 188-205, Feb. 2009.

[22] C. Gorgan, V. Gorgan, V. F. Dumitru, and I. C. Pitulice, "the Evolution of the Accounting Practices During the Recent Economic Crisis : Empirical Survey Regarding the Earning Management," Amfiteatru Econ. J., vol. 14, no. 32, pp. 550-563, 2012.

[23] R. B. Cialdini and N. J. Goldstein, "Social influence: compliance and conformity.," Annu. Rev. Psychol., vol. 55, no. 1974, pp. 591-621, 2004
[24] F. Bova and R. Pereira, "The determinants and consequences of heterogeneous IFRS compliance levels following mandatory IFRS adoption : evidence from a developing country," J. Int. Account. Res., vol. 11, no. 1, pp. 83-111, 2012.

[25] M. D. Beneish, "The Detection of Earnings Manipulation," Financ. Anal. J., vol. 55, no. 5, pp. 24-36, 1999.

[26] M. S. Beasley, J. V Carcello, and D. R. Hermanson, "Fraudulent Financial Reporting: 1987-1997 An Analysis of U.S. Public Companies Research," 1999.

[27] M. S. Beasley, J. V Carcello, D. R. Hermanson, and T. L. Neal, "Preventing Fraudulent Financial Reporting," CPA J., vol. 70.12, pp. 14-21, 2000.

[28] C. Ton, "IFRS and Earnings Management: Aggregate accrual approach on Dutch listed companies," Erasmus School of Economics, 2011 